\title{
Perkembangan Sistem Pemerintahan dan Konsep Kedaulatan Pasca Revolusi Perancis Terhadap Hukum Internasional
}

\author{
Sandy Kurnia Christmas ${ }^{1 *}$, Evi Purwanti2 \\ 1Program Studi Magister Ilmu Hukum, Fakultas Hukum, Universitas Diponegoro \\ 2Fakultas Hukum, Universitas Tanjungpura \\ *ch.sandykurnia@gmail.com
}

\begin{abstract}
The French Revolution was an event that caused a social change and political-cultural shift. This revolution is shaping ideologies such as liberalism, democracy, and nationalism that have an impact on the change of government system and sovereignty. What is the pattern of the French Pre-Revolutionary government system, and what changes have led to the development of international law in the aftermath of the French Revolution. This article aims to examine historically how a historical event has brought significant changes to the pattern of government systems used today. This research method uses normative legal research, where the assessment uses a conceptual approach and historical approach. The results of this study concluded that the ideologies that formed during the French Revolution, such as Liberalism, Democracy, and Nationalize major impact on the change of government system that prioritizes the interests of the people and the development of international law. The pattern of the French Pre-Revolutionary government system in the form of Monarchy, in fact, failed many times and was considered to be too pressing for the people. The change in the pattern of the government system that was triggered by the French Revolution was considered as a people's revolution because it created many forms of good state order, which became the ideals of the people who were influential until now.
\end{abstract}

\section{Keywords: The French Revolution; Government system; Sovereignty Concept.}

\begin{abstract}
ABSTRAK
Revolusi Perancis merupakan sebuah peristiwa yang menyebabkan perubahan sosial dan pergeseran budaya politik. Revolusi ini membentuk paham-paham seperti Liberalisme, Demokrasi, dan Nasionalisme yang berdampak pada perubahan sistem pemerintahan dan kedaulatan. Bagaimana pola sistem pemerintahan Pra-Revolusi Perancis, serta apa perubahan yang berdampak membawa perkembangan hukum internasional Pasca Revolusi Perancis. Artikel ini bertujuan untuk mengkaji secara historis bagaimana sebuah peristiwa sejarah membawa perubahan yang signifikan terhadap pola sistem pemerintahan yang sampai sekarang digunakan. Metode penelitian ini menggunakan penelitian hukum normatif, dimana pengkajian menggunakan pendekatan konseptual dan pendekatan historis. Hasil penelitian ini menyimpulkan bahwa paham-paham yang terbentuk saat terjadinya Revolusi Perancis, seperti Liberalisme, Demokrasi, dan Nasionalise berdampak besar terhadap perubahan sistem pemerintahan yang lebih mengutamakan kepentingan rakyat serta perkembangan hukum internasional. Pola sistem pemerintahan Pra-Revolusi Perancis berbentuk Monarki nyatanya banyak mengalami kegagalan dan dianggap terlalu menekan rakyat. Adanya perubahan terhadap pola sistem pemerintahan yang dipicu oleh Revolusi Perancis dianggap sebagai revolusi rakyat karena banyak menciptakan berbagaii bentuk tatanan konsep negara yang baik yang menjadi cita-cita rakyat yang berpengaruh hingga sekarang.
\end{abstract}

Kata Kunci : Revolusi Perancis; Sistem Pemerintahan; Konsep Kedaulatan. 


\section{A. PENDAhULUAN}

Revolusi Perancis merupakan sebuah masa terjadinya pergeseran terhadap kultur masyarakat serta perubahan sistem poltik di Perancis yang memiliki dampak besar di Eropa secara keseluruhan, dimana peristiwa ini berlangsung dari tahun 1789 hingga 1814. Peristiwa Revolusi Perancis terjadi dengan tujuan untuk menghapuskan absolutisme yang terjadi selama berabad-abad di Perancis, serta untuk memperjuangkan hak-hak rakyat akibat kesewenang-wenangan Kerajaan Perancis pada masa itu. Revolusi Perancis dianggap mendudukan harkat dan martabat manusia pada tempatnya yang tepat $(A z, 2014)$.

Pada masa pemerintahan Kerajaan Perancis sebelum peristiwa Revolusi Perancis terjadi, sistem pemerintahan Monarki Absolut telah lama diterapkan berabad-abad di kerajaan tersebut. Hingga akhirnya Monarki Absolut tersebut runtuh seketika karena pecahnya peristiwa Revolusi Perancis tersebut. Revolusi Perancis menjadi peristiwa transformasi politis, dimana dinamika perubahannya mengarah pada politik revolusioner (Hanson, 2019). Terjadinya transformasi sosial politik di Perancis juga menandakan berakhirnya paham-paham seperti feodalisme, aristokrasi, dan monarki di Perancis. Terjadinya Revolusi Perancis ini dikarenakan adanya ketidakpuasan rakyat terhadap pemerintahan Raja Louis XVI saat krisis terjadi di Kerajaan tersebut. Kekuasan raja Luis XVI dengan semboyannya "I'Etat, c'est Moi" atau "Negara adalah Aku" menjadi puncak dari pemerintahan absolutisme di Perancis (Sungkar, 2007). Ambisi untuk menumbangkan sistem kerajaan yang terjadi berabad-abad ini juga dikarenakan pengaruh aliran "Pencerahan" atau "Aufklarung" oleh kaum terpelajar, kaum petani, kaum buruh, serta individu masyarakat yang merasa tersakiti pada masamasa tersebut (Sondarika, 2017).

Revolusi Perancis dikenal dengan tiga semboyannya, yaitu "Liberte, Egalite, et Fraternite" atau "Kebebasan, Persamaan, dan Persaudaraan", dimana merupakan suatu gagasan yang ingin dicapai dalam memperjuangkan hak asasi manusia mereka. Upaya Revolusi Perancis yang dilakukan untuk menggulingkan kekuasaan kerajaan ternyata berhasil. Adanya perubahan tatanan hukum dan konstitusi melahirkan sebuah deklarasi bernama "Deklarasi Hak Asasi Manusia dan Warga Negara 1789" atau "La Declaration Des Droits De L'homme Et Du Citoyen 1789". Selain lahirnya sebuah deklarasi tersebut, perjuanganperjuangan tersebut juga melahirkan suatu pahampaham baru seperti Liberalisme, Demokrasi, dan Nasionalisme yang terlahir dari tiga semboyan revolusi tersebut. Tokoh-tokoh pemikir itu seperti Hugo Grotius, Montesquieu, Jean Jacques Rousseau, Abbe Mably, dan Condorcet, serta John Locke (Az, 2014). Paham-paham dan pemikiran ide tantang konsep negara tersebutlah yang membuat hukum internasional mulai berkembang. 
Pekembangan hukum pada abad ini juga karena adanya pengaruh dari peradaban Yunani, Mesir Kuno, dan Romawi Kuno yang kemudian diadaptasikan menjadi sebuah budaya yang bernama "Renaisans". "Renaisans" merupakan sebuah gerakan budaya yang berkembang pada masa abad ke-14 hingga abad ke-17, dimana paham ini berkontribusi dalam perkembangan observasi, diplomasi, dan peningkatan ilmu pengetahuan. Renaisans dianggap mewariskan prasyarat pemikiran independen, kritis, dan pendekatan humanistik, serta kerangka hukum politiik dimasa depan (Shaw, 2008). Adanya perkembangan didalam hukum internasional ini dilihat dari adanya perkembangan di bidang politik, hukum, budaya, ideologi, dan masih banyak lagi. Perkembangan hukum pada aspek politik dapat dilihat dari sebelumnya adanya pengaruh penguasa duniawi dan gerejawi, yang rata-rata menguasai beberapa aspek dalam sebuah kerajaan, seperti ekonomi, agama, ideologi, dan kultural.

Terjadinya perkembangan hukum di era Revolusi Perancis pada dasarnya membawa perubahan dalam aspek hak asasi manusia dan konsep kenegaraan didalam hak-hak kedaulatan. Perkembangan selanjutnya didalam hukum internasional terjadi karena adanya hubungan antar negara-negara atau bangsa-bangsa yang berdaulat. $\mathrm{Hal}$ ini dilihat dengan adanya "The Treaty of Westphalia 1648" yang terjadi sebelum Revolusi Perancis. Hal ini membuktikan perkembangan hukum internasional sudah mulai berkembang di masa lampau. Secara historis, hubungan antara hukum dan sejarah dalam perkembangannya adalah tentang kebiasaan internasional yang merupakan sumber hukum tertua (Sunyowati, 2013). Hukum Internasional diartikan sebagai keseluruhan hukum yang didalamnya terkadnung prinsip, kaidah, dan perilaku antar negara yang mengikatkan dirinya kedalam suatu hubungan antar negara, sehingga harus ditaati setiap negara (Kuahaty, 2014).

Konsep negara didalam hukum internasional tidak terlepas dari adanya hubungan antara negara-negara yang berdaulat, dimana mereka melakukan sebuah kerjasama dalam diplomasi hukum. Konsep Kedaulatan pertama kali dianalisis pada tahun 1576 dalam karya "Six Livres de la Republique" oleh Jean Bodin. Konsep kedaulatan menurut Jean Bodin menekankan pentingnya sebuah kekuasaan yang berdaulat didalam suatu negara yang akan membuat hukum. Meskipun pemegang kekuasaan tersebut tidak terikat oleh hukum yang di lembagakan sendiri, namun dapat tunduk atas hukum Tuhan dan alam dalam paham Teologi. Hal ini juga menurut Jean Bodin bahwa "Kedaulatan merupakan sumber utama untuk menetapkan hukum. Kedaulatan merupakan sumber otoritas yang berada pada arah tertinggi dalam hierarki hukum (legal hierarchy)" (Riyanto, 2012). Konsep Kedaulatan ini nantinya menjadi sebuah landasan dari sistem nilai khas yang melahirkan hubungan internasional dan hubungan 
Jurnal Pembangunan Hukum Indonesia

Volume 2, Nomor 2, Tahun 2020
Program Studi Magister IImu Hukum Fakultas Hukum Universitas Diponegoro antarbangsa, diman menjadi dasar alasan bahwa kedaulatan didalam hukum internasional mempunyai sebuah ikatan yang tidak dapat dipisahkan.

Revolusi Perancis dijadikan sebagai momentum untuk melakukan perubahan yang sebenarnya telah terpikirkan diera sebelumya, namun terkekang oleh keterbatasan hak asasi karena masih tetap terjadinya imperialisme dan kolonialisme. Revolusi Perancis juga menjadi pemicu lahirnya revolusi lainnya sampai abad ke20 karena dianggap sebagai gerakan menuju kebebasan dunia. Universalitas Revolusi Perancis dalam paham-pahamnya diikuti oleh beberapa revolusi lainnya seperti Revolusi Batavia (1794), Revolusi Swiss (1798), Revolusi Spanyol (1820), Revolusi Rusia (1905), Revolusi Tiongkok (1949), hingga Revolusi Kuba 1965) (Az, 2014).

Revolusi Perancis dianggap sebagai peristiwa yang membawa perubahan dan perkembangan yang sangat politis dibidang hukum. Eksplorasi terhadap literatur sejarah Revolusi Perancis menjadi sebuah literatur yang mengkaji sejarah awal perkembangan konsepkonsep hukum. Pada kasusnya, Revolusi Perancis membawa perubahan didalam hak asasi manusia dan konsep kedaulatan, karena pasca terjadinya Revolusi Perancis, beberapa wilayah mengembangkan konsep, paham, serta perjuangan yang sama dalam upaya membebaskan diri dari penindasan absolutisme dan monarki. Revolusi Perancis dijuluki sebagai revolusi politik dan sosial, karena menyebabkan pergeseran budaya. Adanya perkembangan budaya, munculnya norma-norma baru, serta praktik sosial budaya dan kepercayaan religius yang turut bergeser menyebabkan terjadinya perubahan dalam budaya politik. Hal inilah yang menyebabkan pergeseran budaya merupakan pendorong revolusi sosiopolitik, bukan hanya sekedar perubahan nilai dan norma (Rosenfeld, 2019).

Berdasarkan sejarah Revolusi Perancis tersebut, ada beberapa faktor yang menjadi dasar berkembangnya ilmu hukum, salah satunya mengenai konsep kedaulatan. Konsep Kedaulatan diyakini sudah lama ada, namum implementasi pemikirannya berbeda-beda. Sebagai contoh pada masa abad ke-14 hingga abad ke-17, Sistem pemerintahan berbentuk Kerajaan menkonsepsikan dirinya berdasarkan kedaulatan Tuhan dan kedaulatan Raja, namun pasca terjadinya Revolusi Perancis muncul adanya Kedaulatan Negara dan Kedaulatan Rakyat. Hal tersebut ditandai dengan adanya perubahan sistem pemerintahan di Perancis yang sebelumnya sistem Monarki Absolut Kerajaan menjadi sistem pemerintahan Republik. Konsep kedaulatan tidak terlepas dari konsep negara dalam hubungan hukum antara negara-negara.

Penulis melihat bahwa penting untuk meneliti dan membahas dalam penelitian ini mengenai pola sistem pemerintahan dan konsep kedaulatan pada masa Pra-Revolusi Perancis dan 
Jurnal Pembangunan Hukum Indonesia

Volume 2, Nomor 2, Tahun 2020
Program Studi Magister IImu Hukum Fakultas Hukum Universitas Diponegoro perkembangan sistem pemerintahan dan konsep kedaulatan Pasca Revolusi Perancis terhadap hukum internasional.

Penelitian yang menganalisis mengenai perkembangan sistem pemerintahan dan konsep kedaulatan pasca Revolusi Perancis belum pernah dikaji pada penelitian jurnal ilmiah sebelumnya. Penelitian oleh Sigit Riyatno berjudul "Kedaulatan Negara dalam Kerangka Hukum Internasional Kontemporer" membahas mengenai kedaulatan negara ada dalam konsep dasar hukum internasional, dimana mengkaji kedaulatan negara dalam hubungan antar negara (Riyanto, 2012). Hal yang membedakan dengan penulisan penelitian ini adalah konsep mengenai kedaulatan negara dikaji dengan asal-usul historis melalui peristiwa Revolusi Perancis, sehingga ide-ide mengenai Kedaulatan Negara yang berkembang tersebut dapat dipahami sejarahnya.

Penelitian oleh Kiki Mikail berjudul "Sistem Politik Iran Kontemporer : Dari Westernisasi hingga Islamisasi" membahas mengenai perubahan sistem politik di Iran pada masa Revolusi Iran, dimana tujuan revolusi ini bermaksud untuk menguatkan paham-paham mengenai keislaman dan menghindari pengaruh paham barat (westernisasi) Amerika (Mikail, 2019). Perbedaannya dengan penelitian ini adalah unsur kebaharuan dalam penelitian ini lebih memfokuskan kepada dampak yang berkembang dan meluas bukan saja terhadap negara yang melakukan revolusi, melainkan dampak secara luas terhadap negara-negara lain juga.

Penelitian oleh Mohamad Rosyidin berjudul "Dari Otoritarianisme ke Demokrasi : Bagaimana Mendorong Negara Menuju Kestabilan dan Keterbukaan?" membahas mengenai fenomena demokratisasi, dimana strategi dalam upaya mendorong perubahan politik dapat memperkuat perlembagaan politik. Penelitian ini mengkaji bahwa tidak semua hak pada negara-negara yang menjalankan demokrasi menjamin hak-hak rakyatnya, faktanya negara-negara Otoriter yang tidak menjamin hak-hak sipil dan poltik justru jarang terjadi gejolak, hal ini memunculkan apakah setiap terjadinya perubahan sistem pemerintahan dapat merubah kestabilan negara (Rosyidin, 2013). Penelitian ini pada dasarnya memiliki persamaan bagaimana upaya mengubah sistem pemerintahan yang dapat memicu terjadinya ditengah-tengah masyarakat. Unsur kebaharuan dalam penelitian ini bahwa selain menggunakan unsur historis, penelitian ini juga mengkaji menggunakan aspek-aspek politik, hukum, dan sosial yang terjadi. Hal inilah yang menghasilkan tujuan bahwa perubahan sistem pemerintahan bukan merupakan kehendak penguasa, melainkan rakyat.

Pada penelitian jurnal ilmiah internasional, ada beberapa penelitian membahas mengenai Revolusi Perancis. Penelitian oleh Paul R. Hanson berjudul "Political History of the French Revolution Since 1989" membahas mengenai aspek-aspek 
sejarah politik secara eksplisit dari Revolusi Perancis. Penelitian ini pada dasarnya membahas bagaimana pengaruh politik yang terjadi pasca Revolusi Perancis (Hanson, 2019). Unsur kebaharuan penelitian ini bahwa pengaruh yang terjadi pasca Revolusi Perancis bukan saja mempengaruhi aspek politik, melainkan sisi hukum, budaya, dan sosial yang dapat dilihat dari pengaruh semboyan Revolusi yang berdampak luas.

Penelitian oleh Anthony Crubaugh berjudul "Local J ustice and Rural Society in the French Revolution" membahas mengenai dampak sosial yang terjadi akibat revolusi, dimana dampak tersebut tidak hanya dirasakan masyarakat kota, melainkan masyarakat pedesaan merasakan dampak terhadap perubahan realitas hukum dan pemahaman mengenai kewarganegaraan yang dimilikinya (Crubaugh, 2000). Adapun perbandingan dengan jurnal tersebut memiliki unsur kebaharuan, dimana dampak yang terjadi pada Revolusi Perancis tidak hanya mempengaruhi dampak secara sosial, melainkan hukum dan sistem pemerintahannya. Inovasi pembaruan dalam penelitian ini lebih mengkaji sisi hukum didalam perubahan sistem pemerintahan dan konsep kedaulatan yang digunakan.

\section{B. METODE PENELITIAN}

Penelitian yang bersumberkan dengan fakta sejarah ini diteliti dengan menggunakan penelitian hukum normatif, dimana pengkajiannya berdasarkan Pendekatan Sejarah (Historical Approach) dan Pendekatan Konseptual (Conceptual Approach).

Penelitian ini menggunakan bahan hukum primer dan bahan hukum sekunder sebagai dasar hukumnya. Bahan hukum primer itu berbentuk konvensi, perjanjian, traktat, piagam, maupun deklarasi, seperti Charter of The United Nations 1945 (Piagam Perserikatan Bangsa-Bangsa 1945), The Universal Declaration of Human Rights 1984 (Deklarasi Universal Hak Asasi Manusia 1948), Declaration Des Droits De L'homme Et Du Citoyen 1789 (Deklarasi Universal Hak Asasi Manusia dan Warga Negara 1789) dan beberapa instrumen hukum lainnya. Sedangkan bahan hukum sekunder diambil berdasarkan sumber-sumber hukum online dan offline berupa buku, jurnal, artikel, dan beberapa penelitian hukum dan sejarah lain yang relevan dalam penelitian ini.

\section{HASIL DAN PEMBAHASAN}

\section{Pola Sistem Pemerintahan dan Konsep Kedaulatan Pra-Revolusi Perancis}

Negara merupakan sebuah wilayah kedaulatan, yang dapat disebut sebagai suatu organisasi kekuasaan yang memilkik unsur-unsur terbentuknya negara, seperti pemerintahan yang berdaulatan, wilayah, rakyat, dan pengakuan dari negara lain. Menurut Aristoteles (384-322 SM), Negara dibentuk dengan tujuan mencapai kebaikan yang tertinggi terhadap rakyatnya, hal ini 
Jurnal Pembangunan Hukum Indonesia

Volume 2, Nomor 2, Tahun 2020
Program Studi Magister IImu Hukum Fakultas Hukum Universitas Diponegoro dianggap bahwa negara dapat mensejahterakan rakyatnya didalam suatu wilayah.

Pada dasarnya negara dipandang sebagai institusi sosial dan kenyataan sosial yang menunjukkan adanya pola antara manusia dengan ikatan kehendak golongan masyarakat, dan negara dipandang sebagai entitas dalam jumlah besar yang mencakup golongan masyarakat tersebut (Usman, 2015). Negara dipandang sebagai suatu sistem norma yang memiliki kesatuan dan kekhasan sehingga pantas disebut sebagai suatu tatanan hukum.

Konsep kedaulatan dalam hal ini berkaitan dengan terbentuknya suatu negara. Terbentuknya suatu negara terjadi karena orang-orang yang mempunyai kesamaan, baik itu nasib, budaya, kepentingan, dan lainnya, membentuk suatu kelompok (genossenchaft) yang dipimpin oleh seseorang. Hal inilah yang membedakan setiap negara memiliki tujuan yang berbeda. Tujuan negara berdasarkan teori tujuan negara memiliki tiga tujuan, yaitu negara yang bertujuan kebahagiaan hidup manusia sebagai tujuan akhir manusia; negara yang bertujuan untuk menimbulkan negara kekuasaan (machtstaat) ; serta negara yang bertujuan untuk mencari kemakmuran (Soemarsono, 2007). Oleh karena itu peran negara sangatlah penting, dimana harus ada sinergi antara pemerintah yang berdaulat dan rakyat.

Peristiwa Revolusi Perancis yang terjadi dari tahun 1789 hingga 1799 menjadi bagian penting dari adanya pergeseran sistem pemerintahan yang sebelumnya berbentuk Kerajaan menjadi sebuah Negara Republik. Peristiwa tersebut ditandai dengan penggulingan kekuasaan Raja Louis XVI yang dianggap tidak berkompeten dalam menyingkapi persoalan negara dalam menjalankan pemerintahan pada saat itu. Pemerintahan yang dijalankan oleh Raja Louis XVI berbentuk monarki telah diterapkan selama berabad-abad di Kerajaan Perancis. Pemeritahan Monarki merupakan jenis pemerintahan yang dikepalai oleh seorang Raja atau Ratu.

Pada prakteknya, jenis pemerintahan monarki ada dua, yaitu Monarki Absolut dan Monarki Konstitusional. Monarki Absolut adalah model pemerintahan yang kekuasaan tertingginya dipegang langsung oleh satu orang raja atau ratu. Model kekuasaan absolut ini selalu memperlakukan "sebuah subjek" sebagai bentuk pemerintahan, dimana artinya apapun yang diinginkan raja atau ratu merupakan sebuah perintah yang harus dijalankan tanpa harus dikaji atau diirumuskan terlebih dahulu sebuah perintah tersebut (Daly, 1978). Bentuk monarki yang secara historis sangat nyata adalah monarki absolut yang terjadi di Eropa selama abad ke-18. Dibawah bentuk pemerintahan ini yang juga dikenal sebagai despotisme, tatanan hukum dalam seluruh tahapan dibuat dan diterapkan baik secara langsung oleh raja, maupun organ-organ yang diangkat oleh raja. Sedangkan Monarki Konstitusional adalah bentuk pemerintahan yang 
Jurnal Pembangunan Hukum Indonesia

Volume 2, Nomor 2, Tahun 2020
Program Studi Magister IImu Hukum Fakultas Hukum Universitas Diponegoro kekuasaan kepala negara dipegang oleh perdana menteri yang dibatasi oleh ketentuan-ketentuan konstitusi negara.

Pemerintahan Monarki dianggap menjadi masalah besar dalam suatu pemerintahan, hal ini terbukti dengan munculnya berbagai Revolusi didunia, khususnya Perancis. Absolutisme yang diterapkan menjadi penghalang bagi kebebasan seseorang. Hal inilah juga menjadi suatu penghalang terhadap hak asasi manusia. Ditambah lagi dengan pembagian kelas atau kasta dalam masyarakat menjadi jurang pemisah antara si kaya dan si miskin.

Berdasarkan Teori Kedaulatan, memandang sistem pemerintahan monarki sebagai Teori Kedaulatan raja, karena kekuasaan dikendalikan langsung oleh raja. Hal ini dianggap bahwa kekuasaan raja berada diatas konstitusi sehingga dianggap tidak perlu mentaati norma-norma hukum lainnya. Raja pada masa sistem permerintahan Monarki selalu direpresentasikan sebagai wakil Tuhan, sehingga tidak jarang kekuasaan tersebut bersifat tirani.

Sistem pemerintahan yang diterapkan selama abad pertengahan (abad ke-16 sampai ke18) menerapkan dua teori kedaulatan, yaitu Teori Kedaulatan Tuhan dan Teori Kedaulatan Raja. Representasi dari kedua teori ini terlihat dari siapa yang memimpin. Keterlibatan Paus dalam suatu pemerintahan dianggap sebagai aturan mutlak yang menganggap bahwa perintahnya merupakan perintah dari Tuhan, dan gereja menjadi penyalur pesan dalam menyampaikan perintahnya. Oleh karena itu sifat absolutisme ini menjadi suatu penentang bagi sebagian orang yang membenci aturan atau perintah yang dibuat secara sewenang-wenang.

Sebelum terjadinya Revolusi Perancis, tidak ada pemisahan antara urusan negara dengan urusan agama. Keduanya dianggap sama dalam wujud untuk menjalankan roda pemerintahan. Hubungan antar Negara dengan agama ini disebut Teokrasi. Teokrasi adalah bentuk pemerintahan dimana prinsip-prinsip ilahi memegang peranan utama atau bisa dikatakan sebagai sistem pemerintahan yang menjunjung dan berpedoman pada prinsip ilahi. Teokrasi direpresentasikan sebagai Kedaulatan Tuhan karena kekuasaan tertinggi berasal dari Tuhan. Namun hakikat ini berubah setelah mengalami distorsi yang digunakan untuk melanggengkan kekuasaan para diktator oleh para Raja atau Ratu pada masa pemerintahan Monarki (Wahyuni, 2012).

Bentuk pemerintahan Teokrasi dapat dikatakan lemah karena menimbulkan perspektif yang negatif. Hal ini dapat dilihat dari adanya golongan "Etats Rohaniawan" atau "Etats Kedua", dimana golongan ini dianggap terlalu dekat dengan pemerintahan sehingga menimbulkan banyak permasalahan seperti korupsi dan perilaku sewenang-wenang dari kaum rohaniawan. Padahal jika melihat dari tugas dan tanggungjawabnya sebagai kaum rohaniawan, 
Jurnal Pembangunan Hukum Indonesia

Volume 2, Nomor 2, Tahun 2020
Program Studi Magister IImu Hukum Fakultas Hukum Universitas Diponegoro seharusnya lebih dekat kepada rakyat dan memiliki peran dalam pembentukan karakter umatnya.

Sistem pemerintahan kerajaan yang turuntemurun juga menjadi penyebab kekuasaan hanya berpusat kepada ikatan keluarga kerajaan. Sistem pemerintahan yang hanya dipegang oleh satu orang (Otokrasi) menyebabkan tidak ada yang dapat membatasi kekuasaan Raja, sehingga rentan terjadinya permasalahan, seperti krisis ekonomi, kelaparan, utang negara, penjajahan dari negara lain, dan sebagainya.

Pemerintahan Monarki dikategorikan sebagai konsep otokrasi, sedangkan pemerintahan republik dikategorikan sebagai konsep oligarki. Menurut Robert Barros, "Otokrasi adalah aturan seseorang atau sekelompok orang yang arogan pada diri mereka sendiri dan memonopoli kekuasaan di negara bagian, melaksanakannya tanpa menahan diri" (Barros, 2002). Sedangkan Oligarki menurut Robinson-Hadiz didefinisikan sebagai sebuah sistem relasi kekuasaan yang menghubungkan antara negara dan kaum borjuis, dimana konsentrasi kekayaaan yang terdapat pada kaum borjuis dipadukan antara akulmulasi kekayaan dan kekuasaan politik (Ananta, 2016).

Adanya perubahan ini terjadi karena ketidaksenangan rakyat kepada sistem pemerintahan yang lama, yang dalam hal ini bersifat feodalisme, aristokrasi, dan monarki, sehingga rakyat dengan inisiatif mengambil alih kekuasaan pemerintah. Rakyat menjadi penyelenggara kesejahteraan dan bertanggungjawab terhadap hal tersebut. Pengambil alihan kekuasaan pemerintah ini dianggap sebagai langkah dalam menjunjung tinggi sekaligus memperjuangkan hak asasi manusia yang mereka miliki.

Runtuhnya Monarki Absoulut Raja Louis $\mathrm{XVI}$, tidak serta merta membuat Perancis langsung berganti ke sistem pemerintahan Republik. Gerakan revolusi yang dilakukan oleh Rakyat secara langsung menyebabkan belum dapat menetapkan pemimpin dalam pemerintah selanjutnya. Oleh karena itu jatuhnya pemerintahan Monarki Absolut diganti dengan pemerintahan Monarki Konstitusional sebagai jalan untuk merumuskan konstitusi negara dan perlengkapan aparatur negara.

\section{Perkembangan Sistem Pemerintahan dan Konsep Kedaulatan Pasca Revolusi Perancis terhadap Hukum Internasional}

Keruntuhan Monarki Absolut menjadi pertanda revolusi yang dijalankan rakyat Perancis berhasil. Setelah pemerintahan Monarki Absolut diganti dengan pemerintahan Monarki Konstitusional, Majelis Konstituante Nasional dibentuk untuk menghapuskan feodalisme yang terjadi selama berabad-abad tersebut. Majelis Konstituante Nasional membentuk sebuah dokumen bernama "Dekret Agustus" yang bertujuan menghapuskan seluruh hak istimewa. Pembentukan dokumen tersebut kemudian melahirkan sebuah deklarasi HAM bernama "Deklarasi Hak Asasi Manusia dan Warga Negara 
Jurnal Pembangunan Hukum Indonesia

Volume 2, Nomor 2, Tahun 2020
Program Studi Magister IImu Hukum Fakultas Hukum Universitas Diponegoro
1789" atau "La Declaration Des Droits De L'homme Et Du Citoyen 1789". Majelis Konstituante Nasional dibentuk tidak hanya berfungsi sebagai badan legislatif, melainya sebagai badan yang menyusun konstitusi baru. Hal inilah yang kemudian melahirkan Negara Republik Perancis.

Terbentuknya Republik Perancis merupakan negara pertama yang mendeklarasikan negaranya sebagai negara republik di Eropa. Pada bentuk pemerintahan Republik ini, kekuasaan tertinggi bersumber kepada rakyat. Menurut John Locke sebagai pelopor Teori Kedaulatan Rakyat menyatakan bahwa kekuasaan bukanlah milik Raja yang memimpin, melainkan milik rakyat yang dipimpin. Karena pada hakikatnya, kekuasaan timbul akibat adanya perjanjian masyarakat, dimana rakyat menyerahkan hak-hak rakyat kepada pemerintah untuk diatur, dan kekuasaan pemerintah mengembalikan hak tersebut melalui hak dan kewajiban yang diatur dalam bentuk peraturan perundang-undangan. Perjanjian masyarakat tersebut dikenal dalam buku John Locke "Du Contract" sebagai "Kontrak Sosial", dimana bertujuan untuk membentuk badan yang diberikan kekuasaan untuk menyelenggarakan ketertiban masyarakat (Fahmi, 2010). Adanya kedaulatan suatu negara pada dasarnya mengarahkan hak negara untuk secara bebas menentukan status politik, struktur sosial, ekonomi, dan budaya dalam wilayah tersebut (Christmas \& Seetiyono, 2019).
Revolusi Perancis diidasari oleh paham Liberalisme, Demokrasi dan Nasionalisme, dimana paham-paham inilah yang kemudian berkembang dalam hukum internasional. Paham Liberalisme menurut Max Weber dianggap pandangan mengenai individu yang bebas untuk memilih nilainya sendiri (Bakar, 2012). Paham Demokrasi diartikan sebagai sebuah mekanisme politik dalam menentukan pendapat dan memilih pemimpinnya Demokrasi direpresentasikan sebagai kebebasan hak dalam berpendapat dan memilih pemimpinnya sendiri (Nugroho, 2012). Sedangkan Nasionalisme diartikan sebagai sebuah paham kebangsaan yang dimiliki oleh rakyatnya dalam sebuah negara. Sikap kebangsaannya tersebut muncul karena sifat kecintaannya terhadap negara karena memiliki sejarah dan cita-cita yang sama dalam membentuk negara, serta persamaan cita-cita dan tujuan bangsa (Alfaqi, 2015).

Pembentukan Republik Perancis juga dianggap sebgai langkah awal dalam penghapusan golongan atau kelas dalam strata sosial masyarakat. Hal ini kemudian melahirkan paham sekularisme, dimana menurut paham ini menyatakan sebuah intitusi atau badan negara harus terpisah dari unsur agama dan kepercayaan. Paham ini menjelaskan pemisahan antara urusan negara dan urusan agama. Sehingga Sekularisme dipandang sebagai paham yang menunjang kebebasan beragama dan kebebasan dari pemaksaan kepercayaan dengan menyediakan sebuah kerangka yang netral, serta memahami 
Jurnal Pembangunan Hukum Indonesia

Volume 2, Nomor 2, Tahun 2020
Program Studi Magister IImu Hukum Fakultas Hukum Universitas Diponegoro bahwa menyelesaikan suatu permasalahhan tanpa mengatasnamakan sebuah agama tertentu. Paham inilah yang kemudian menjadi prinsip utama dalam pemisahan gereja dan negara dalam mengurusi persoalan negara.

Perkembangan sistem pemerintahan pasca Revolusi Perancis dilihat dari terbentuknya suatu negara. Teori Perjanjian Masyarakat dan Teori Kedaulatan Rakyat menciptakan suatu perangkat berbentuk badan atau lembaga yang diangkat oleh rakyat untuk melindungi kepentingan rakyat, termasuk hak asasi manusia. Hak asasi manusia yang terbentuk merupakan sebuah cita-cita dari rakyat yang menumpahkan darahnya untuk menghapus penindasan yang terjadi selama berabad-abad dengan menegaskan kebebasan manusia.

Revolusi Perancis nyatanya tidak hanya membawa perubahan dalam perkembangan sistem pemerintahan, melainkan kepada penegakan hak asasi manusia juga diperjuangkan. Implikasi lahirnya paham-paham Liberalisme, Demokrasi, dan Nasionalisme membawa perubahan yang signifikan terhadap sistem pemerintahan. Terbentuknya elemen-elemen pendukung dalam kontrak sosial melahirkan badan-badan legislatif, eksekutif, dan yudikatif didalam Trias Politika.

Perkembangan hukum internasional yang terjadi pasca Revolusi Perancis membawa perubahan terhadap hubungan antara negara. Hal ini dapat dilihat bahwa paham-paham yang lahir dari Revolusi Perancis diadopsi oleh beberapa wilayah. Perkembangan hukum internasional yang dapat dilihat pasca Revolusi Perancis yaitu secara sistem pemerintahan, bentuk pemerintahan Republik telah hampir diterapkan diseluruh daratan Eropa (kecuali Kerajaan Inggis), bahkan sampai ke negara-negara di Asia, Afrika, dan Amerika. Hal inilah yang menyebabkan Eropa sebagai pusat episentrum negara Republik.

Selain dari perkembangan sistem pemerintahan, perkembangan selanjutnya berasal dari penalaran paham Liberalisme yang berkembang. Paham ini dikatakan sebagai paham kebebasan yang tidak hanya menjalar di bidang politik, melainkan di bidang ekonomi, budaya, dan bidang lainnya. Di bidang Ekonomi dapat dilhat dengan terbentuknya Masyarakat Ekonomi Eropal European Economic Community yang lahir dari kebebasan dalam melakukan kegiatan ekonomi dan perdagangan.

Penalaran dalam paham Demokrasi menjadi sebuah bukti bahwa negara tersebut menjunjung tinggi kedaulatan rakyat. Hal ini dibuktikan dengan dijalankannya pemungutan suara, baik kepada lembaga, oeganisasi, maupun oeang, dalam memilih hak suara mereka. Penaalaran mengenai demokrasi ini juga melahirkan aparatur pemerintahan dengan memilih siapa saja yang diangkat oleh rakyat sebagai pemangku pemerintahan di lembaga eksekutif, legislatif, dan yudikatif. Perkembangan hukum internasional pasca Revolusi Perancis ini juga membentuk 
Jurnal Pembangunan Hukum Indonesia

Volume 2, Nomor 2, Tahun 2020
Program Studi Magister IImu Hukum Fakultas Hukum Universitas Diponegoro

hubungan kerjasama antar negara dalam pemerintahan yang sebelumnya hanya membantu negara-negara membentuk tatanan berdasarkan ikatan keluarga kerajaan atau kaum bersama-sama. Karena pada hakikatnya, kelas atas, menjadi semua rakyat berhak membentuk suatu perjanjian antar negara harus menentukan pemimpin mereka sendiri dalam memiliki kedaulatan negara.

\section{SIMPULAN}

Revolusi Perancis menjadi sebuah peristiwa penting yang membawa perubahan terhadap sistem pemerintahan yang baru serta konsep kedaulatan. Sebelum terjadinya Revolusi Perancis, kekuasaan yang dikendalikan oleh raja dalam sistem pemerintahan monarki selalu direpresentasikan sebagai pemerintahan tirani yang absolut, dimana pemerintahan terbentuk oleh raja dan untuk raja, sehingga tidak jarang kekuasaan yang dikendalikan oleh raja atau ratu secara langsung tidak memperhatikan hak-hak rakyatnya, hal ini seringkali menyebabkan krisis ditengah-tengah masyarakat. Sistem Pemerintahan Monarki pada dasarnya hanya mementingkan kesejahteraan kelas atas dan menengah. Pasca terjadinya Revolusi Perancis pemisahan kelas tersebut dihapuskan seiring dengan penghapusan sistem pemerintahan monarki yang dianggap tidak berperikemanusiaan.

Kebebasan hak pasca Revolusi Perancis selalu menjadi perhatian, karena pasca Revolusi Perancis tersebut melahirkan paham-paham baru seperti Liberalisme, Demokrasi, dan Nasionalisme. Paham-paham baru ini, terutama mengenai paham Demokrasi dianggap mengubah sistem 


\section{DAFTAR PUSTAKA}

\section{JURNAL}

Alfaqi, Mifdal Z. (2015). Memahami Indonesia

Melalui Prespektif Nasionalisme, Politik Identitas, Serta Solidaritas. Jurnal Pendidikan Pancasila dan Kewarganegaraan, Vol.28, (No.2), pp.111116. DOI: http://dx.doi.org/ 10.17977/jppkn.v28i2.5451.

Ananta, Dicky D. (2016). Politik Oligarki dan Perampasan Tanah di Indonesia : Kasus Perampasan Tanah di Kabupaten Kerawang Tahun 2014. Jurnal Politik, Vol.2, (No.1), pp.101-135.

DOI: https://doi.org /10.7454/jp.v2i1.83.

Bakar, Muhammad Yunus A. (2012). Pengaruh Paham Liberalisme dan Neolibearlisme Terhadap Pendidikan Islam di Indonesia. J urnal Tsaqafah, Vol.8, (No.1), pp.135-160. DOI: http://dx.doi.org/10.21111/tsaqafah.v8i 1.22.

Christmas, Sandy Kurnia \& Setiyono, Joko. (2019). Intervensi Militer Terhadap Kudeta Politik Menurut Prinsip Jus Cogens. Jurnal Pembangunan Hukum Indonesia, Vol.1, (No.3), pp.308-321. DOl: https://doi.org /10.14710/jphi.v1i3.308-321.

Crubaugh, A. (2000). Local Justice and rural Society in the French Revolution. J ournal of Social History, Vol.34, (No.2), pp.327-350.

Daly, J. (1978). The Idea of Absolute Monarchy in Seventeent-Century England. The Historical
J ournal, Vol.21, (No.2), pp.227-250. DOI: https://doi.org/10.1017/S0018246X0000052 2.

Fahmi, K. (2010). Prinsip Kedaulatan Rakyat Dalam Penentuan Sistem Pemilihan Umum Anggota Legislatif. J urnal Konstitusi, Vol.7, (No.3), pp.119-160. DOI: https://doi.org/ 10.31078/jk\%25x.

Hanson, Paul R. (2019). Political History of the French Revolution Since 1989. J ournal of Social History, Vol.52, (No.3), pp.584-592. DOI : https://doi.org/10.1093/jsh/shy075

Kuahaty, Sarah S. 2014. Pengaruh Hukum Internasional Terhadap Perkembangan Hukum Kontrak Di Indonesia. J urnal Sasi, Vol.20, (No.2), pp.64-70.

Mikail, K. (2019). Sistem Politik Iran Kontemporer : Dari Westernisasi Hingga Islamisasi. J urnal Inteletualika : Keislaman, Sosial, dan Sains, Vol.8, (No.2), pp.139-148.

Nugroho, H. (2012). Demokrasi dan Demokratisasi : Sebuah Kerangka Konseptual Untuk Memahami Dinamika Sosial-Politik di Indonesia. J urnal Pemikiran Sosiologi, Vol.1, (No.1), pp.1-15. https://doi.org/ 10.22146/jps.v1i1.23419.

Riyanto, S. (2012). Kedaulatan Negara Dalam Kerangka Hukum Internasional Kontemporer. Yustisia J urnal Hukum, Vol.1, (No.3), pp.5-14. DOl: https://doi.org/ 10.20961/yustisia.v1i3.10074. 
Jurnal Pembangunan Hukum Indonesia

Volume 2, Nomor 2, Tahun 2020

Rosenfeld, S. (2019). The French Revolution in Cultural History. J ournal of Social History, Vol.32, (No.3), pp.555-565. DOI https://doi.org/10.1093/jsh/shy078.

Rosyidin, M. (2013). Dari Otoritarian Ke Demokrasi

: Bagaimana Mendorong Negara Menuju Kestabilan dan Keterbukaan ?. Jurnal Penelitian Politik, Vol. 10, (No.1), pp.155160.

Soemarsono, M. (2007). Negara Hukum Indonesia Ditinjau Dari Sudut Teori Tujuan Negara. Jurnal Hukum dan Pembangunan, Vol.37, (No.2), pp.299-322. DOI: http://dx.doi.org/ 10.21143/jhp.vol37.no2.1480.

Sondarika, W. (2017). Peranan Golongan Borjuis Dalam Revolusi Perancis 1789. Jurnal Wahana Pendidikan. Vol.4 (No.2). pp.1-7

Sungkar, L. (2007). Peranan Golongan Borjuis Pada Revolusi Perancis Tahun 1789. J urnal Sejarah Citra Lekha, Vol.11, (No.1), pp.5967.

Sunyowati, D. (2013). Hukum Internasional Sebagai Sumber Hukum Dalam Hukum Nasional (Dalam Perspektif Hubungan Internasional dan Hukum Nasional di Indonesia). Jurnal Hukum dan Peradilan, Vol.2, (No.1), pp.67-84. DOI: http://dx.doi. org/10.25216/JHP.2.1.2013.67-84.

Usman. (2015). Negara dan Fungsinya (Telaah atas Pemikiran Politik). Jurnal Hukum Pidana \& Ketatanegaraan : Al-Daulah, Vol.4,
Program Studi Magister IImu Hukum Fakultas Hukum Universitas Diponegoro

(No.1), pp.130-140. DOI: https://doi.org/ 10.24252/ad.v4i1.1506.

Wahyuni, S. (2012). Demokarsi dan Negara Hukum Dalam Islam. J urnal Review Politik, Vol.2, (No.2), pp.153-173.

\section{BUKU}

Az., Lukman S. (2014). Para Martir Revolusi Dunia. Yogjakarta : Palapa

Barros, R. (2002). Constitutionalism and Dictatorship : Pinochet, The J unta, and the 1980 Constitution. United Kingdom : Cambridge.

Shaw, Malcom N. (2008). International Law. United Kingdom : Cambridge University Press 